\title{
Pathogenicity of Entomopathogenic Fungi on the Weevil of the Andes (Premnotrypes vorax Hustache) of the Potato (Solanum tuberosum L.) in Chimborazo Province, Ecuador
}

\author{
Erazo Sandoval N. S.
}

Doctor en Ciencias Ambientales de la Universidad Nacional San Marcos (UNMSM) Lima Perú: Profesora a Tiempo Completo de la Escuela Superior Politécnica de Chimborazo

Lindao Córdova $V$. A.

Doctor en Ciencias Ambientales de la Universidad Nacional San Marcos (UNMSM) Lima Perú: Profesor ocacional Tiempo Completo de la Escuela Superior Politécnica de Chimborazo

\section{Echeverría Guadalupe M. M.}

Doctor en Ciencias Ambientales de la Universidad Nacional San Marcos (UNMSM) Lima Perú: Centro de Investigación de Energía Renovable y Medio Ambiente (CEAA-ESPOCH). Profesora Tiempo Completo de la Escuela Superior Politécnica de Chimborazo

\section{Manzano Ocaña J. C.}

Ingeniero Agronómo, Técnico de Investigación, Tiempo Completo de la Escuela Superior Politécnica de Chimborazo

\section{Inca Chunata N. M.}

Master en docencia Universitaria y Administración educative. Profesora a Tiempo Completo de la Escuela Superior Politécnica de Chimborazo

Doi: 10.19044/esj.2018.v14n27p205 URL:http://dx.doi.org/10.19044/esj.2018.v14n27p205

\begin{abstract}
From thirty native isolates of entomopathogenic fungi, which were obtained from corpses of larvae and adults of Andean weevil (Premnotrypes vorax Hustache); two fungi with entomopathogenic characteristics were selected through laboratory tests, which will be used in a program of integrated management of this pest in the Ecuadorian inter-Andean region. The pathogenicity of the 30 isolates was determined by the mortality that they caused in larvae and adults and it was expressed in percentage; for this, a complete randomized design (CRD) was used. The $\mathrm{LC}_{50}$ and $\mathrm{TL}_{50}$ were determined by Probit analysis. The two selected isolates corresponded to: Metarhizium anisopliae (Metschnikoff 1879) Sorokin 1883 (A13) and
\end{abstract}


Beauveria bassiana (Bals.-Criv.) Vuill. 1912 (A21), which proved to be the best, because they caused the highest mortality in larvae of the fourth instar and adults of $P$. vorax. The Probit analysis showed that $\mathrm{LC}_{50}$ for $\mathrm{A} 21$ isolate (B. bassiana) in fourth instar larvae was obtained with a concentration of $1,75 \times 10^{9}$ spores $/ \mathrm{ml}$ and $1,08 \times 10^{9}$ spores/ml for adults. Instead for A13 isolate (M. anisopliae), the $\mathrm{LC}_{50}$ was obtained with a concentration of $1,65 \times 10^{9}$ spores/ml for larvae and $2,42 \times 10^{9}$ spores $/ \mathrm{ml}$ for adults. The $\mathrm{LT}_{50}$ for the selected isolates at the indicated concentrations, was 4,84 and 4,32 days for larvae with A13 and A21 isolates respectively, while, for adults, the shortest time was obtained with A21 isolate in 4.36 days, compared with A13 isolate, that delayed 20,70 days. The larval stage of $P$. vorax was the most susceptible to A13 isolate, on the other hand, larvae and adults were equally susceptible to A21 isolate at the indicated concentrations. According to the results obtained, the two selected isolates can be used as an alternative to the use of conventional agrochemicals, which will contribute to a more ecological production.

Keywords: Entomopathogenic fungi, Potato cultivation, Conventional agrochemicals.

\section{Introduction}

Weevil of the Andes (Premnotrypes vorax) is the main pest of potato cultivation in many places in Chimborazo province. The attack of this pest produces a great variety in the tubers, this larvae can consume almost all of them, decreasing the quality of the product, causing considerable losses in harvest (CIP, 2013).

To control this pest, farmers have resorted to the use of chemical synthesis pesticides, which have not reduced the damage caused by this pest. Rather, they have created a resistance to chemicals, which causes greater damage (Argenpapa, 2016). Some farmers perform crop rotation, which is a temporary solution to reduce the populations of this pest. However, this plague persists in neighbouring fields, which hinders a true reduction of the population (Salamanca, 2013).

In addition, it is important to note that, because the climatic conditions of some places in Chimborazo province, this favour the Potato farming throughout the year, making it possible to find the crop in all the phenological stages, making it difficult even more establish an effective control program. In most case they use dangerous pesticides, those that have seriously affected the health of producers, consumers and the environment (Basantes, 2015).

Therefore, it is important to develop alternative methods of combating this pest. Entomopathogenic fungi can be the alternative solution to fight the weevil (Delgado \& Murcia, 2011). 
Entomopathogenic fungi infect all insects, mainly: Hemiptera, Diptera, Coleoptera, Lepidoptera, Hymenoptera and Orthoptera (Ferron, 1981). In some insect orders, immature stages (nymphs or larvae) are more susceptible to infection than adults (González, Aguilar, \& Rodríguez, 2012).

Approximately 100 genera and 700 species of entomopathogenic fungi are known. Among the most important genera are the fungi: Beauveria bassiana (Bals.) Vuill, Cephalosporium sp, Meharhizium anisopliae var. Anisopliae (Metch) Sorokin, Lecanicidium (Verticillum) lecanii, Paecilomyces fumosoroseus (Wize) Brown y Smith, Aschersonia aleyrodis Webber (Borges, Díaz, San Juan, \& Gómez, 2010).

Of the genera cited, Beauveria and Metarhizium are found infecting the weevil of the Andes potato. These fungi have a considerable epizootic potential, can spread rapidly through a population and can cause death within a few days. Infected insects stop feeding and can die relatively quickly. Sometimes, they are covered by the mycelium of the fungus. In order circumstances, it is observed emerging from the joints and segments of the body (Tanada \& Kaya, 1993). Therefore, they can be isolated, selected and multiplied to be used in massive applications, considering that the spread of the disease depends on the interactions and factors related to: 1) The pathogen (pathogenicity, virulence, dispersion and persistence); 2) the host (susceptibility, density and distribution, behaviour) and 3) the environment (abiotic: temperature, humidity, wind, rainfall, and biotic: parasites, predators, host plant) (Gallegos, Ávalos, \& Castillo, 1997).

The variety of fungus change considerably, some fungi infect a wide range of hosts and others are restricted to a few or a single insect species. Beauveria bassiana and Metarhizium anisopliae infect about 100 different species of insects in several orders, but isolates of these two species have a high degree of specificity (García, Cappello, Lesher, \& Molina, 2011).

Beauveria, is one of the most important pathogens that affect several species of insects that includes whiteflies, aphids, grasshoppers, termites, beetles, weevils, chiggers, ants and butterflies. The species Beauveria bassiana has been the most studied. The different Beauveria isolates exhibit considerable variation in virulence. In laboratory tests, there was a $100 \%$ mortality of the adults of Premnotrypes suturicallis, after 2 weeks of inoculation of the fungus to the neck of the plant. Beauveria is used as a bioinsecticide in some countries and is currently found in the markets of some European markets in commercial form under the name of Beauverin or Boverin (Alcalá \& Alcázar, 1999).

Metarhizium spp is another fungus that has been proven as a natural enemy of several species of insects, such as Diabrotica spp, weevils and other beetles. It has a wide range of hosts; it is used extensively in Brazil in alfalfa 
and sugarcane crops to fight bedbugs of the Cercopidae family (Nicholls, 2008).

The objective of this research was to search for effective isolates of entomopathogenic fungi for the management of the Andean weevil (Premnotrypes vorax Hustache) in Chimborazo province.

\section{Materials and methods:}

It was used: a) soil samples from fields infested by the pest and b) corpses of larvae and adults of $P$. vorax, found with signs of fungal infection, in 3 storage warehouses of potatoes from the city of Riobamba.

\subsection{Induced infection}

For the first case, the soil samples were placed in one litter plastic containers, humidity was corrected to $60 \%$ and for each container 30 healthy larvae of $P$. vorax were added from the fourth instar. The same ones that came from a breeding, method called "induced infection". After an incubation period of 10 days at $20^{\circ} \mathrm{C}$, the larvae were removed, washed, disinfected with $5 \%$ sodium hypochlorite and rinsed three times in sterile water, before being transferred to a chamber individual incubation, until observing growth of mycelium or spores.

\subsection{Isolation}

Isolation, identification, production of spores of native isolates, mortality of isolates on populations of larvae and adults of white worm breeding, medium lethal concentration $\left(\mathrm{LC}_{50}\right)$ and mean lethal time $\left(\mathrm{LT}_{50}\right)$ in larvae and adults of P. vorax was determined by Probit analysis and carried out in the Biological Sciences laboratory at Escuela Superior Politécnica de Chimborazo.

\section{Results and Discussion:}

Thirty isolates were obtained in monosporic cultures, which were identified as Beauveria bassiana (A21) and Metarhizium anisopliae (A13).

\subsection{Mortality of larvae of the fourth instar of $P$. vorax caused by A21 and A13 isolates}

Of the thirty native evaluated isolates on larval stage L4 of $P$. vorax, A21 (B. bassiana) and A13 (M. anisopliae) isolates, with a concentration of $10^{7}$ spores $/ \mathrm{ml}$ caused $100 \%$ death of larvae at seven days. The witness presented an average mortality of $13 \%$, lower than all the isolates evaluated (Fig.1).

The A21 (Beauveria bassiana) and A13 (Metarhizium anisopliae) isolates, present a great potential to be taken into account in a control program 
of the white potato worm, however, they could be important controllers for other pests, for example Mendoza, Gómez \& Gualle (2008) reported up to $36 \%$ adult mortality of the banana weevil (Cosmopolites sordidus Germar) and up to $80 \%$ on the sugarcane weevil (Metamasius hemipterus Olivier) in the countryside, when they used banana pseudo stem traps with $5,8 \times 10^{10}$ conidia/trap (10 g/trap).

\subsection{Determination of the mean lethal concentration (LC50) and mean lethal time (LT50) in larvae and adults of P. vorax}

The Probit analysis shows that for A13 isolate (Metarhizium anisopliae), the mortality trend increases with the concentration of spores in both larvae and adults, however, in adults a lower mortality is observed than in larvae (Fig. 2).

Similarly, with the A21 isolate (Beauveria bassiana) the mortality with the highest concentration of spores increases, but the effect is apparently similar in both larvae and adults, which makes this isolate promising for the control of this pest in the two states, as shown in Fig. 3.

The mean lethal concentration of A13 isolate (Metarhizium anisopliae), for fourth-instar larvae, was $1,65 \times 10^{9} ; 9,44$ and 2,39x $10^{8}$ spores/ml on the third, fifth and seventh days respectively. For adults, the mean lethal concentration was recorded at 2,42;2,26; and 2,10x109 spores $/ \mathrm{ml}$ for the third, fifth and seventh day.

For A21 isolate (Beauveria bassiana), the mean lethal concentration in larvae of fourth instar was $1,75 \times 10^{9}$ spores/ml at 3 days; 6,28 and $7,3 \times 10^{8}$ spores/ml at 5 and 7 days. For adults, the mean lethal concentration was $1,08 \times 10^{9}$ spores/ml, 9,55 and 9,00× $10^{8}$ spores/ml at 5 and 7 days under laboratory conditions.

The period in which death occurs is between three and seven days, depending on the amount of inoculum, which is similar to the data obtained by Storey \& Gardner (1988), who indicate that a greater amount of infective propagules increases the probability of infection and consequently the death of insects (Table 1).

Table 1. Mean lethal concentration of the A21 and A13 isolates as a function of the time of

P. vorax

\begin{tabular}{|c|c|c|c|}
\hline & \multicolumn{3}{|c|}{ Larvae L4 } \\
\hline \multirow{2}{*}{ Isolates } & LC50 & $\mathrm{LC}_{50}$ & LC $_{50}$ \\
\hline & 3 DAYS & 5 DAYS & 7 DAYS \\
\hline A13 & $1,65 \mathrm{E}+09$ & $9,44 \mathrm{E}+08$ & $2,39 \mathrm{E}+08$ \\
\hline \multirow[t]{2}{*}{ A 21} & $1,75 \mathrm{E}+09$ & $6,28 \mathrm{E}+08$ & $7,3 \mathrm{E}+08$ \\
\hline & Adults & & \\
\hline \multirow[t]{2}{*}{ Isolates } & $\mathrm{LC}_{50}$ & $\mathrm{LC}_{50}$ & $\mathbf{L C}_{50}$ \\
\hline & 3 DAYS & 5 DAYS & 7 DAYS \\
\hline A13 & $2,42 \mathrm{E}+09$ & $2,26 \mathrm{E}+09$ & $2,10 \mathrm{E}+09$ \\
\hline $\mathrm{A} 21$ & $1,08 \mathrm{E}+09$ & $9,55 \mathrm{E}+08$ & $9,00 \mathrm{E}+08$ \\
\hline
\end{tabular}




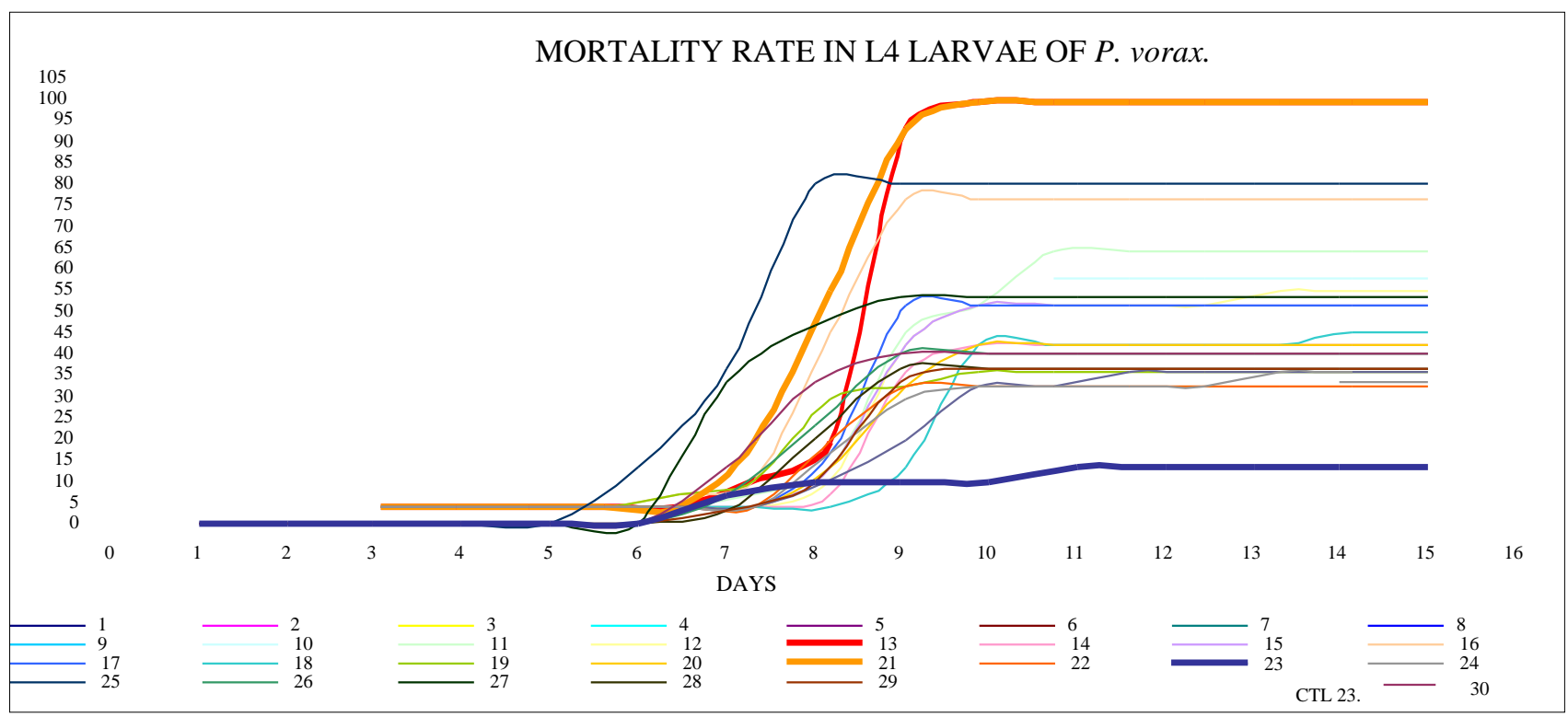

Fig. 1. Mortality expressed as a percentage, caused by isolates of native entomopathogenic fungi in L4 larvae of $P$. vorax.
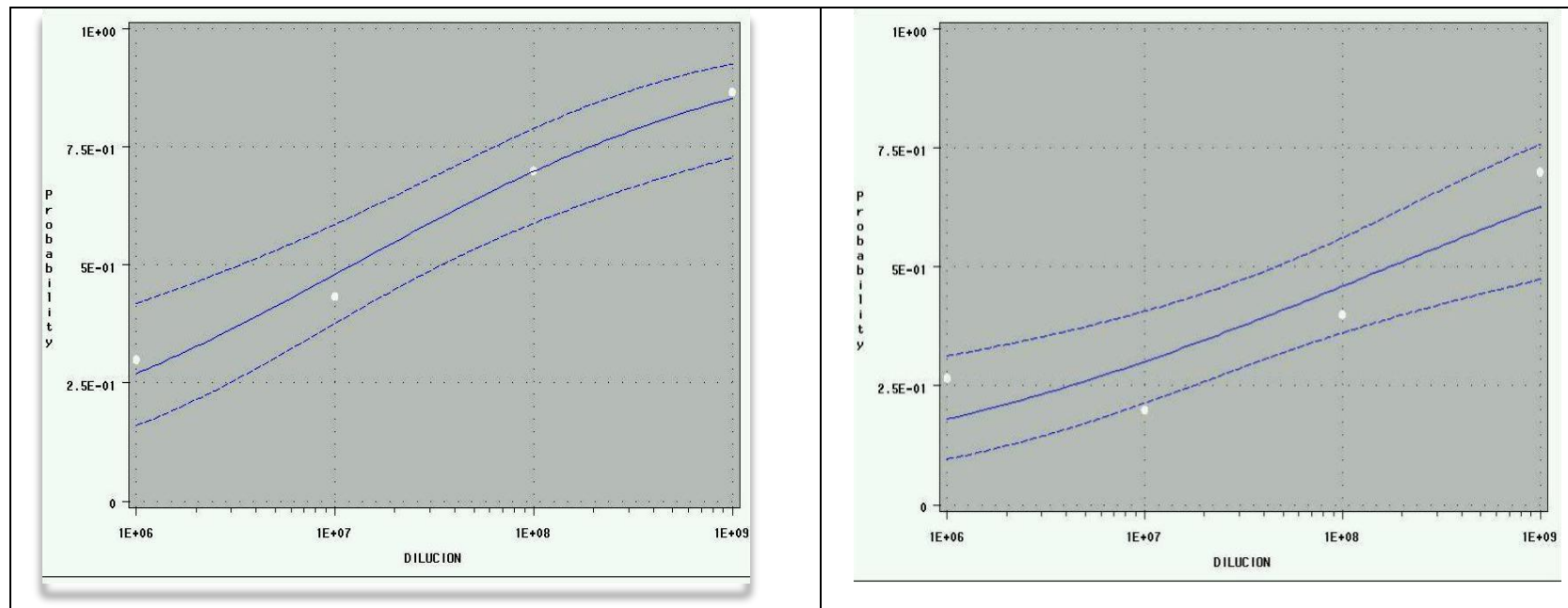

Fig. 2. Mean lethal concentration $\left(\mathrm{LC}_{50}\right)$ caused by the $\mathrm{A} 13$ isolate (Metarhizium anisopliae) in L4 larvae and adults of $P$. vorax. 

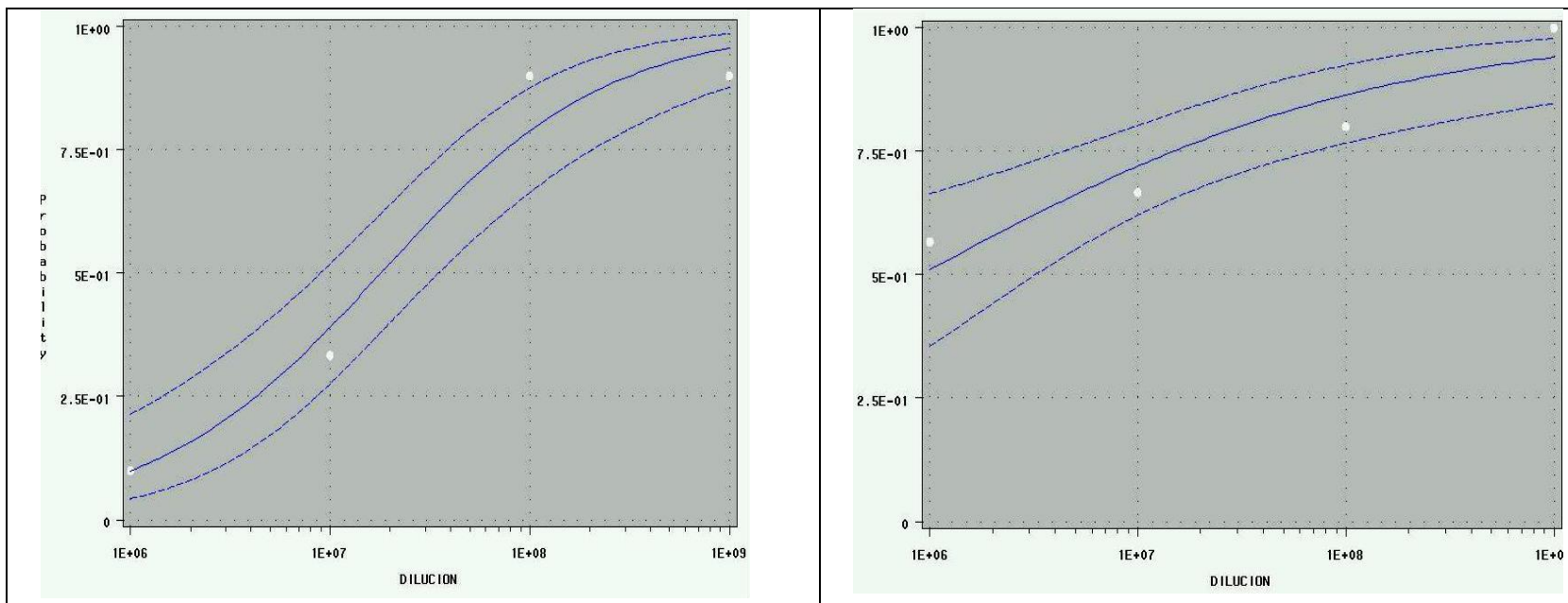

Fig. 3. Mortality caused by A21 isolate (Beauveria bassiana) in L4 larvae and adults of $P$. vorax.

The results show that, mortality is a function of the state of the pest (larvae or adults) and the isolation and concentration of spores per millilitre (Nicholls, 2008). For a good management of this pest, concentration must be applied differentially. In addition, it is important to take into account the particular conditions that each agroecosystem presents.

The mean lethal time of the selected isolates decreases as the concentration of spores per millilitre increases for the two isolates, both in larvae and adults. However, it is important to note that the A13 isolate ( $M$. anisopliae) with a concentration of $10^{9}$ spores $/ \mathrm{ml}$ is not effective for adults of $P$. vorax, because the $\mathrm{LC}_{50}$ is recorded on the twenty-first day, different from the A21 isolate (B. bassiana) that causes considerable mortality on the fourth day at a concentration of $10^{9} \mathrm{spores} / \mathrm{ml}$. However, lower concentrations of $10^{8}$, $10^{7}$ and $10^{6}$ spores $/ \mathrm{ml}$ cause a $50 \%$ mortality from the nineteenth day.

These results indicate that A21 isolate (B. bassiana) is feasible to be used in a control program of $\mathrm{kg}$ both in the larval and adult phases, since it produces a higher mortality rate the fifth day. However, a concentration of $10^{9}$ spores/ml should be applied in the adult stage to achieve the same effect, since lower concentrations do not achieve adequate control of this pest, without forgetting the behaviour of this pest in potato fields, where adults tend to oviposit in early stages of the crop. Therefore applications should be made at the beginning of the first phenological stage of this crop (Gallegos, Ávalos, \& Castillo, 1997).

The A13 isolate (M. anisopliae) proved to be a good controller of this pest only in the larval stage, which indicates that a good controller depends on 
the isolation, concentration, state of the pest and, of course, environmental conditions (Table 2).

Table 2. Mean lethal time of the isolates selected at different concentrations for the control of P. vorax.

\begin{tabular}{|c|c|c|c|c|}
\hline \multirow{2}{*}{$\begin{array}{l}\text { Stages of the } \\
\text { insect }\end{array}$} & \multicolumn{4}{|c|}{ Spore concentration/ml } \\
\hline & $10^{9}$ & $10^{8}$ & $10^{7}$ & $10^{6}$ \\
\hline \multicolumn{5}{|l|}{ Larvae } \\
\hline A13 (days) & 4,84 & 7,39 & 7,65 & 7,66 \\
\hline A21 (days) & 4,32 & 5,94 & 6,10 & 6,12 \\
\hline \multicolumn{5}{|l|}{ Adults } \\
\hline A13 (days) & 20,70 & 31,92 & 33,04 & 33,16 \\
\hline A21 (days) & 4,26 & 19,08 & 20,56 & 20,71 \\
\hline
\end{tabular}

\section{Conclusions:}

The A21 isolate was found to be the best for larvae of the fourth instar and adults of $P$. vorax, because it caused the highest mortality.

The A13 isolate was considered to be good for larvae in the fourth instar, however, for adults, mortality was recorded around day 21 with a concentration of $10^{9}$ spores $/ \mathrm{ml}$.

The $\mathrm{LC}_{50}$ of the A21 isolate was $10^{9}$ spores $/ \mathrm{ml}$ on the fourth day. Minor concentrations of the same isolate of $10^{8}, 10^{7}$ and $10^{6}$ spores $/ \mathrm{ml}$ cause a $50 \%$ mortality only from the nineteenth day.

The A21 isolate could be used in an integrated management program of $P$. vorax, both in the larval and adult phases, since it produces a $50 \%$ mortality of the population around the 4th day. However, concentrations of $10^{9}$ spores/ml should be applied in the adult stage to achieve the same effect.

\section{Acknowledgements:}

We would like thank to the International Potato Center Staff (CIP) in Peru and also to the scientific team of Escuela Superior Politécnica de Chimborazo, for their valuable scientific, economic and technical contribution.

\section{References:}

1. Alcalá, P., \& Alcázar, J. (1999). Biología y Comportamiento del Gorgojo de los Andes. Memorias. Cochabamba: CIP. Programa Andino Cooperativo de Investigación en Papa. Retrieved from http://sisbib.unmsm.edu.pe/BVRevistas/entomologia/v19/pdf/a10v19 . $\mathrm{pdf}$

2. Andrews, F., et al. (1998). Selecting Statistical Techniques for Social Science Data: A Guide for SAS ${ }^{\circledR}$ Users. Cary, North Caroline: SAS Institute Inc. Retrieved from https://books.google.com.ec/ books?id=Q0k93Scia9Q C\&pg=PP4\&lpg=\#v=onepage \&q\&f=false

3. Argenpapa. (2016). Manejo de Premnotrypes vorax (gusano blanco) en Cultivo de papa.. Retrieved from http://www.argenpapa. 
com.ar/noticia/2427-manejo-de-premnotrypes-vorax-gusa no-blancoen-cultivo-de-papa

4. Basantes, E. (2015). Manejo de cultivos andinos del Ecuador. Sangolquí, Ecuador : Universidad de las Fuerzas Armadas ESPE. Retrieved from https://repositorio.espe.edu.ec/bitstream/21000/10163/4/Manejo\%20 Cultivos\%20 Ecuador.pdf

5. Borges, D., Díaz, A., San Juan, A., \& Gómez, E. (2010). Metabolitos secundarios producidos por hongos entomopatógenos. ICIDCA, 44(3): 49-55. Retrieved from http://www.redalyc. org/pdf/2231/ 223120684008.pdf

6. CIP. (2013). Manejo de gusano blanco. Retrieved from https:/cipotato.org/en/region-quito-2/manejo-de-gusano-blanco-3/

7. Delgado, P., \& Murcia, B. (2011). Hongos entomopatógenos como alternativa para el control biológico de plagas. Revista Ambiente \& Água, 6(2), 77-90. Retrieved from http://www.ambiagua.net/seer/index.php/ambi-agua/arti cle/view File/465/pdf_455

8. Ferron, P. (1981). Pest Control by the fungi Beauveria and Metarhizium. In FAO (Ed.). New York, 949 p. : Burges, H. ed. Microbial control of pests and plant diseases Academic Press.

9. Gallegos, P., Ávalos, G., \& Castillo, C. (1997). El gusano blanco de la papa en Ecuador. Comportamiento y control. Quito, Ecuador: Programa Nacional de Raíces y tubérculos. INIAP. Retrieved from http://repositorio.iniap.gob.ec/bitstream/41000/3257/1/iniapsc144.pdf

10. García, M., Cappello, S., Lesher, J., \& Molina, R. (2011). Aislamiento y caracterización morfológica de los hongos entomopatógenos Beauveria bassiana y Metarhizium anisopliae. Horizonte Sanitario, 10(2),21-28. Retrieved from http://www.redalyc.org/pdf/4578/457845138002.pdf

11. González, M., Aguilar, C., \& Rodríguez, R. (2012). Control de insectos-plaga en la agricultura utilizando hongos entomopatógenos: Retos y perspectivas . Acta Química Méxicana, 4(8), 42-55. Retrieved from http://www.posgra doeinvestigacion.uadec.mx/Documentos/AQM/AQM8/5 .pdf

12. Mendoza, J., Gómez, P., \& Gualle, D. (2008). Posibilidades del uso de Beauveria bassiana y Metarhizium anisopliae para el control del picudo rayado (Metamasius hemipterus) en caña de azúcar. CINCAE. 7 p. Retrieved from https://cincae.org/wpcontent/uploads/2013/05/Posib.-uso-B.-bassiana-paraMetamasius.pdf

13. Nicholls, C. (2008). Control biológico de insectos: un enfoque agroecológico. Medellín, Colombia: Editorial Universidad de 
Antioquia. 261 p. Retrieved from http://es.calameo.com/read/ $004043336303700 \mathrm{a} 03285$

14. Salamanca, F. (2013). Gorgojo de los Andes. Retrieved from https://www.croplifela.org/en/plagas/ listado-de-plagas/ gorgojo-delos-andes

15. Storey, \& Gardner. (1988). Movement of an aqueous spray of Beauveria bassiana into the profile of four Georgia soils. Environmental Entomology, 17(1), 135-139, Retrieved from https://academic.oup.com/ee/articleabstract/17/1/135/338201?redirect edFrom=fulltext

16. Tanada, Y., \& Kaya, H. (1993). Insect Pathology. Davis-California: Academic Press Inc. 622 p. Retrieved from https://books.google.com.ec/books?id=99YwOQnsgGUC\&printsec=f rontcover\&hl=es\&source $=$ gbs_ge_summary_r\&cad $=0 \# \mathrm{v}=$ onepage $\&$ $\mathrm{q} \& \mathrm{f}=$ false 